\title{
Should California Adopt Federal Civil Procedure?
}

\author{
Louis E. Goodman**
}

WHILE What we are pleased to call "civilization" has made us more comfortable, it has, none the less, greatly complicated our lives. The simple process of feeding, clothing and sheltering our people has now become so complex that a single human mind cannot perspectively see it all. Production, manufacturing, distribution separately are enmeshed in state and interstate regulatory intracacies.

Concomitantly, so it is with the litigative processes. Man's inherent urge to dispute as to civil rights has entered an almost infinite number of new fields. When life was relatively simple, with respect to food, clothing and shelter, there was time to "play" with litigative formulae. The legal artisan concentrated on the rules of the game. These rules became what is euphoniously called "common law pleading."

But during the present and past few generations, as the complexity of our economy increased, it became apparent to many leading legal thinkers that civil legal procedures were bogging down and frustrating the accomplishment of justice. Common law pleading was in the main adopted as code pleading in most of the States of the United States. Some of the legal thinkers realized the impossibility of simplifying court procedures by attempting legislative changes. And so it was that the idea that the courts themselves should be given the power to regulate their own procedure by rule took shape. The concept of procedural control in the courts by their own rule making power was finally sanctioned by Congress in 1934 and resulted in the promulgation of Rules of Civil Procedure in the federal courts in 1938. By all older concepts, this in itself was revolutionary. To many, it was shocking that there should be surrendered to the courts the traditional legislative power to delineate court procedure!

But it is now an accomplished fact. The federal courts since 1938, in civil matters, and since 1946, in criminal matters, have been functioning procedurally in accordance with rules which the courts themselves have formulated.

Since 1938 some of the States followed suit, notably Arizona, Colorado, New Mexico, Iowa, Delaware and New Jersey. Texas, Missouri and Maryland were not wholly convinced and adopted some features of the federal procedure. Kentucky is engaged in reconditioning its civil procedure patterned on the federal plan. ${ }^{1}$

Two great States, New York and California, each having much the same code law, have as yet made no move in this direction. Is it not time, now, for the great State of California, typical as it is of the pioneer spirit

*Judge of the United States Court, Northern District of California.

${ }^{1}$ See Holtzoff, Federal Civil Procedure-A Challenge to the States, 40 Ky. L. J. 11 (1951). 
of the West, to move in the direction of federal procedural reform? Let us see.

Almost fourteen years of experience under the Federal Rules of Civil Procedure have passed, as well as six years of experience under the Federal Rules of Criminal Procedure. Eleven volumes of decisions interpreting the Federal Rules have been published by the West Publishing Company since 1940. Much, therefore, can be learned as to the spirit im which the federal courts, im practice, are applying the Rules. And so California has before it, to aid it in its decision, not only the record of the dim past, but also substantial experience in applying the new procedural spirit.

Let us first look at the pleading aspect of civil litigation.

Our inheritance from the common law, stated very succinctly, is that all litigative issues should be delineated in writing, down to the last and most minute detail, before trial. These were the rules of combat. They were imtellectual stimulants to the lawyer pleader. It has been well stated that "common law pleading was the mill of justice $m$ which an indefinable obscure inass of fact was ground down to a clear and distinct issue." In the grimding down process, after the complaint and answer, there were the replication, rejoinder, sur-rejoinder, rebutter, and sur-rebutter, thus moving the pleadings on through what was considered an ideal process, finally to a clear and distinct issue.

In common law courts im England and Scotland, and later in the Umited States, a lawyer's ability for adroit procedural maneuvering in the pleading stage marked him as an attorney of distinction. And this even though it was often invoked to, or had the effect of, depriving a litigant of his day in court. Demurrers, both general and special, motions to dismiss, motions to strike, motions to make more certain, motions for bills of particularsall were the techmiques available to the canny and resourceful, soinetimes as a means of frustration or to delay the final reckoning of the trial.

In the early days of my own practice at the bar, I recall filing a suit for damages for breach of a contract to deliver a carload of eggs. There was no doubt at all that my client had ordered the eggs and that the seller had failed to deliver, mainly because of a rise in the price of eggs above the contract price. My astute and older opponent proinptly demurred specially to the complaint. He averred that the complaint was uncertain because it could not be ascertained therefrom how or in what manner the defendant had failed to deliver the carload of eggs. He also complained that the complamt was ambiguous for the same reason, and then, most heinous and humiliating offense of all, that it was unintelligible. This iniquitous attempt to delay the trial of my client's just claim was, after many delays due to demands for particulars, ultimately defeated. But it was a hollow victory, for by the time the case came to trial the price of eggs had dropped and the defendant was insolvent.

It is not inappropriate here to quote Crogate's historic rejomder to Baron Sur-Rebutter in the equally famous satirical dialogue between them. In answer to Crogate's inquiry as to whether there were any courts 
where justice could be obtained without special pleading, Baron Sur-Rebutter replied that it was possible in the inferior courts. To which Crogate rejoined: "Well, in iny ignorance, I should have thought that would have been the object in great cases as well as small."

To generations of lawyers and judges, the elaborate legal machinery of common law pleading was sacred. To many today it still is sacrosanct. It was only in recent years that the State of Delaware abandoned the archaic common law procedure of "fencing in" the court and the still more ancient artificial technique of "imparling" Richard Roe in ejectunent proceedings. ${ }^{2}$

The predominant force behind the drive for more simplified procedure in the pleading stage of litigation is the realization that, while pleading is the lawyer's function, litigants often lose their day in court through strict and rigid observance of the old pleading formulae.

It is bromidic, but we must constantly remind ourselves, that the object of the litigative process is-justice. And that means, to the best of our abilities, a just result for the litigants. A lawsuit is a part of the living institution of justice. The litigants are live; the lawyers, as actors, are live. But over the decades the parasitic fungi, the technicalities, have attached themselves. And if they be not kept under control, they destroy the living thing. They have been referred to as the "excrescenses of technicality" on the living plant. ${ }^{3}$

Today, even among those who are staunch advocates of the principle and spirit of federal civil procedure, there is diversity of view point as to the need for some changes in the rules. For example, there is a robust controversy as to whether Rule 8 of the Federal Rules of Civil Procedure should not be in some manner amended to require that the pleading state "a cause of action." But such controversies are diversionary. We should not be deterred from reaching the broad objective, well stated in Rule 1, Federal Rules of Civil Procedure, to the effect that the rules shall be construed to secure "the just, speedy and inexpensive determination of every action." For the essence of the new spirit of procedure, as affecting pleadings, is not that, in fact, a cause of action need not be stated, but nierely that it should be stated simply and plainly and in the least possible number of words.4

It has been said that too nuuch siniplification or "notice" pleading makes for "sloppy" lawyership; that it lowers legal thinking to the standard of the poorest thinker; that it is a species of communistic or socialistic dogma, reducing everyone to the level of the lowest. Further, it is claimed that part of the zest of the legal combat will be lost; that it means discarding the learning and scholarship of generations.

$2 \mathrm{~A}$ most interesting and delightful account of these old Delaware practices was given by Hon. John Biggs, Jr. at the 1950 Judicial Conference of the Ninth Circuit, San Francisco, June 28, 1950.

${ }^{3}$ Fee, The Lost Horizon in Pleading Under the Federal Rules of Civil Procedure, 48 Cor. L. REv. 491 (1948).

${ }^{4}$ See McCaskill, The Modern Philosophy of Pleading, 38 A.B.A.J. 123 (1952). 
But is this really so? It is true that what we learn today we sometimes discard tomorrow. But is not that part of the process of learning? Progress does not discard the past, for the past is part of progress. What is fundanentally wrong with using simple furniture to set the stage for justice?

Reluctance to accept the philosophy of the new pleading procedure, is due, in the main, to the failure on the part of many lawyers and some judges, to adequately distinguish between the rationale of the pleading stage of litigation and the trial preparation stage. A pleading is nothing more than a statement of a litigant's claim or of his defense to a claim. In the last analysis, it is what might colloquially be called the "paper work" of litigation. It can be as elaborate and long-winded, or as precise and simple as we will it to be. After all, it is just the preliminary to the main event. When Senator Broderick and Judge Terry fought their famous duel in 1859, in a gully of the present site of the San Francisco Golf Club, a fornal written agreement was drawn up, setting forth in detail the rules and conditions of the duel. This elaborate document was signed by the parties and their seconds. The main event, however, was the duel. The accuracy and elaborateness of the "pleading" meant very little to Senator Broderick, who lost his life in the duel.

So it is that many of us, who have now had some years of experience with the federal pleading rules, have an abiding belief that much of the effort, time, paper and ink consumed in the pleading stage can more effectively be devoted to what we now call the "trial preparation" stage of litigation; and that experience now shows that such a transference of effort makes for much more and speedier justice for litigants.

Let us take a brief look at the effort, time, paper and ink which go into the pleading stage of litigation in the California courts. In the fiscal year ending June 30, 1950, the 203 superior court judges of California heard 13,600 demurrers. In the same period 83 municipal court judges heard 3096 demurrers, a total of 16,696 California demurrers. In 33 per cent of the civil cases in the superior court, excluding domestic relations cases, demurrers were heard. ${ }^{5}$

How many hours of time per judge and per lawyer were consumed in the consideration of 16,696 demurrers? How many tons of paper were used? What a fabulous bonfire the 16,696 demurrers and their accompanying briefs would make for the annual pre-big-game festivities on the Berkeley campus! How much time was spent by the court clerks in entering such demurrers and the decisions thereon in the minute books and court records? A demon with 16,696 heads, each year, takes his place astride the highway to judgment!

No doubt it will be somewhat indignantly countered that there is much unjustified litigation which should be thrown out and that the-denurrer serves to proniptly dispose of such litigation without the unnecessary time and expense of trial.

But the short answer is that summary judgment and discovery and pre-

Statistics taken from the records of the Judicial Council of the State of California. 
trial techniques reach the same end, without too hasty a judgment based only upon pleadings.

The seventeen federal trial judges in Califormia see no demurrers, which have been abolished, and fewer and fewer motions to strike and to make inore certain. Indeed, only those cases which may be disposed of, as a matter of law, are determined in the pleading stage. In difficult or important cases, many federal judges avail themselves of the right to reserve ruling on inotions to dismiss until trial, in order to have a broader vista of the cause before determining the important question of whether the cause should be thrown out of court. ${ }^{6}$

The underlying philosophy of the Federal Rules of Civil Procedure is to allow the widest opportunity and liberality in the obtaining and exchange of information as to factual matters needed for the trial. Both interrogatories and requests for admissions open unlimited fields within which to explore the facts; inspection of any relevant document or writing may be had on motion for good cause. Interrogatories are not limited by orthodox technical rules such as apply in the interrogating of witnesses during trial. Any fact which may reasonably be relevant to a cause, or which may lead to the disclosure of relevant information, is subject to discovery. In fact, as is now well known, almost any relevant report or document, except the work preparation of attorneys, may be opened to pre-trial examination; in addition the traditional method of deposition is, of course, available. ${ }^{7}$ Thus the trial itself becomes less of a game and attorneys need no longer prepare in the dark.

Following after simple pleading and discovery techniques, there is still another procedure which serves to limit the issues of actual trial- the pretrial conference or meeting of judges and lawyers. Here the trial itself can be planned. Documents may be put in evidence, formal proof can be agreed upon, stipulations as to many factual matters may be entered. Proof of many allegations of the pleadings may be eliminated. In fact, in many pretrial conferences, the pleadings nray be dispensed with and the actual issues to be tried can be formulated and reduced to writing in a pre-trial order. True, the advisability of the elimination of the pleadings, and the substitution of a pre-trial order formulating the issues, is still debatable and controversial. In any event, however, it cannot be doubted that, at least in some types of cases, this procedure is effective in accomplishing justice.

Motions for summary judgment are provided for in the Federal Rules. They provide a modus for the prompt disposition of causes without trial, where there is no genuine issue of fact. Califorma provides such procedure. Yet in the fiscal year ending June 30,1950, of 37,593 civil cases terminated, only 164 causes were disposed of in the entire state by summary

${ }^{6}$ FED. R. Crv. P. 12(d) specifically empowers the judge to defer ruling on motions to dismiss for lack of jurisdiction, improper venue, insufficiency of process or its service, failure to state a claim upon which relief can be granted or for judgment on the pleadings, until the trial. In the meantime the responsive pleading is required to be filed.

TSee Wright, Wegner and Richardson, The Practicing Attorney's View of the Utility of Discovery, 12 F.R.D. 97 (1952). 
judgment. And not a single summary judgment was entered in the City and County of San Francisco during the calendar year 1951.

The Federal Rules have not substantially changed trial procedures. But, based upon their philosophy and objectives, the control and supervision of judges over the trial itself has been broadened and emphasized.

It is best illustrated in the procedure of selecting and instructing juries. The federal judge has long exercised the prerogative of questioning jurors in order to determine their eligibility for service. This custom is formalized in the Rules of Civil Procedure. Although the judge may permit counsel to examine jurors, such practices are not generally followed. Judges always, however, put relevant questions requested by counsel.

There can be no doubt that simplicity, fairness and speed result from the judge's examination of prospective jurors. The only objective of jury interrogation is to obtain an impartial jury.

Prolonged interrogation of jurors by counsel to determine how they will weigh certain kinds of evidence does not serve the ends of justice. Its only purpose is to secure jurors who commit themselves in advance. Counsel hopes to obtain a juror favorable to his cause before a single piece of evidence is presented. The be-all and end-all of jury selection is to obtain jurors who have integrity and intelligence enough to impartially listen to and retain in their minds the evidence presented. ${ }^{9}$ Thus it is that the selective process should rest principally in the hands of one who is himself impartial.

In the long run, and over the years of his practice, the lawyer will best serve himself and his clients if impartial jurors are selected. For every juror he gets favorable to his cause, as a result of the long process of ferreting out, opposing counsel is apt to get one or more of the same stripe.

In California much time and expense is devoted to the process of lawyer questioning of jurors. In the fiscal year ending June 30,1950, there were 1842 civil jury verdicts or disagreements in the California superior courts and 223 in municipal courts, a total of 2065 . These figures do not imclude cases settled after jury empanelment. Think of the man hours consumed and the jury fees paid as a result of attorney interrogation of jurors. Contrast this with the systein whereby the judge conducts the jury interrogation.

Let there be no misunderstanding. The interests of justice should never give way to the desire to save time or money. But simplicity and directness in nine cases out of ten not only save time and money but also serve the cause of impartial and fair administration of justice.

By custom carried into the Rules, wide discretion in instructing juries is today entrusted to federal judges. Circuit courts have time and again emphasized the desirability of analysis by the judge of the factual issues and of clear and non-technical statements of the applicable law. The judge

\footnotetext{
8 Hayes v. Missouri, 120 U.S. 68, 71 (1886); Brown v. New Jersey, I75 U.S. 172, 175 (1899); see also Goodman, Federal Jury Selection, 6 F.R.D. 253 (1947).

9 Knox, Selection of Federal Jurors, 31 J. Ax. Jud. Soc'y 9 (1947).
} 
must advise counsel, before they argue the cause, of his ruling on proposed instructions. ${ }^{10}$ This is to better equip the lawyer for his argument. But the judge need not give any of the proposed instructions and may instruct in his own language. Rarely is the judge reversed for failure to give proposed instructions, as long as he fairly states such principles of law as are really pertinent to the issues. In one case, involving the Federal Employers' Liability Act, one counsel submitted to me 125 separate, long and involved instructions. I rejected them all, because I felt that the issue required only one or two simple instructions. The lawyer who proposed these instructions won his case. I seriously doubt the same result if $I$ had taken the 45 minutes or hour required to read the 125 instructions.

California state court judges do not have as much discretion. In effect, the lawyers instruct the jury under state court practice. Instructing the jury becomes a game. The attorneys having the weaker case often aim to confuse the jury. Frequently the object is not to clarify the law to the jury, but to gain advantage or create disadvantage. The judge must rule on each instruction presented, either approving, disapproving or modifying it. It is inevitable that error should frequently enter such a mystic maze. In fact, the present system has been aptly described as a technique of "contrived confusion." 11

Only an extensive investigation could reveal the average number of instructions submitted by each side in negligence cases in California. Even a most cursory snap tally would seem to indicate that between 20 and 100 separate instructions are submitted in the average case. How many would that total up to in 1842 superior court jury cases? Many instructions submitted are repetitious and argumentative. Consider the time and paper work involved. Consider the judicial time necessary to rule upon the proffered instructions. In the fiscal year ending June 30, 1950, there were 50 opinions of the suprene and other appellate courts of California passing upon the sufficiency of instructions. ${ }^{12}$

And these were detailed instructions solemnly read to juries to preserve the fiction, again solemnly recoguized in appellate review, that they actually were well understood by the jury and affected the verdictl Unless we explain the issues to juries in plain language, we will continue to lull ourselves into the pleasant lethargy that we are accomplishing justice by the present mumbo-jumbo.

I am convinced that the many capable trial judges in California automatically go through the process of instructions not because they really think they are guiding juries, but solely to make a record on paper that will stand up on appeal.

Frankly, the words of this article are not intended to be the output of a scholar or deep student of the ramifications of pleadings and practice.

\footnotetext{
10 FED. R. CIV. P. 51.

11 Cook, Instructionese, † J. Mo. BAR 113 (1951).

12 Forty-two in the appellate courts; eight in the supreme court; that means at least four decisions a month on the subject of jury instructions.
} 
They are just the words of a lawyer, who did his chores in the court house for twenty-eight years and on the bench for ten years. They make no pretense of scholarship or erudition. They concern only the effectiveness of justice for the litigant. For I fear that unless we reduce our procedure to more simple terms, we will inevitably founder in the vortex created by our own mental gymnastics. 